\title{
SOUTHERN AFRICAN STUDENTS AT THE MUSIC SCHOOL IN WEIMAR, GERMANY, 1884-1921
}

\author{
Heinrich van der Mescht \\ Department of Music, University of Pretoria, Pretoria, 0002
}

\section{Suider-Afrikaanse studente aan die Hochschule für Musik in Weimar, Duitsland, 1884-1921}

Die Musiekskool in Weimar, een van die beroemdste musiekstede ter wêreld, is in 1872 gestig. Die skool het geleidelik meer studente, ook uit die buiteland, getrek. Die primêre doel van die navorsing was om vas te stel of Suider-Afrikaanse studente aan die skool studeer het, soos wat dit by die konservatoriums in Amsterdam, Leipzig en Wene, die Royal College of Music in Londen, die Stern-Konservatorium in Berlyn en die Hochschule für Musik in Berlyn die geval was. Verrassenderwys het slegs ses studente met Suider-Afrikaanse verbintenisse tussen 1872 en 1939 aan die Musiekskool in Weimar gestudeer. Hulle was Maria Adamson (Kaapstad), Myrtha en Ursula Noyce (Heidelberg, Transvaal), Johanna (Joan) van Niekerk (Uitenhage), Thyra Nissen-Lass (Windhoek) en Anna Maria Bach (Windhoek). Geeneen van hulle word in die programme van studentekonserte genoem nie. 'n Mens moet dus aanneem dat hulle standaard nie goed genoeg was om saam met die ander studente in die openbaar op te tree nie. Maar die buitengewone aktiewe musieklewe by die Musiekskool en in die stadjie Weimar sou aan hulle baie ander musiekervarings verskaf het. Hierdie veelsydige agtergrond sou in hulle latere musieklewens ruimskoots tot hulle voordeel gestrek het. Van die ses studente is slegs Joan van Niekerk vandag nog bekend weens haar Die Groot Afrikaanse-Hollandse Liederbundel (1927) en haar werk as liedbegeleier.

Sleutelwoorde: Anna Maria Bach, Hochschule für Musik Weimar, Johanna (Joan) van Niekerk, Maria Adamson, Musiekskool Weimar, musiekstudente, Myrtha Noyce, Namibië, Suider-Afrika, Thyra Nissen-Lass, Ursula Noyce

The Music School in Weimar, one of the most famous music towns of the world, was founded in 1872. It gradually attracted more students and also more foreigners. The first aim of the research was to establish whether there were Southern African students at this school as there were at the conservatories in Amsterdam, Leipzig and 
Vienna, the Royal College of Music in London, the Stern Conservatorium in Berlin and the Hochschule für Musik in Berlin. Surprisingly, only six students with Southern African connections were found at the Music School in Weimar between 1872 and 1939. They are Maria Adamson (Cape Town), Myrtha and Ursula Noyce (Heidelberg, Transvaal), Johanna (Joan) van Niekerk (Uitenhage), Thyra Nissen-Lass (Windhoek) and Anna Maria Bach (Windhoek). None of these students was mentioned in the programmes of student concerts. One must assume that they were not of a standard to perform in public with the other students. But the extremely active music life at the Music School and in the town of Weimar would have provided them with additional musical experience. This versatile background would have been to their advantage as musicians later in their lives. Among the six students it is only Joan van Niekerk who is known today, for her volume of Dutch Afrikaans songs (1927) and her work as an accompanist.

Key words: Maria Adamson, Anna Maria Bach, Hochschule für Musik Weimar, music students, Namibia, Thyra Nissen-Lass, Myrtha Noyce, Ursula Noyce, Southern Africa, Johanna (Joan) van Niekerk

\section{Introduction}

Many of South Africa's leading young music students embark on overseas studies. They often leave for English-speaking countries like the United Kingdom and the United States of America as the language does not provide difficulties. Communication with loved ones at home in South Africa is nowadays very easy through inexpensive phone calls, e-mail, SMS, facebook and skype. But a hundred years ago the circumstances were totally different and in many respects much more challenging. Nevertheless, a large number of South African students studied in Germany at the Conservatorium der Musik in Leipzig (founded in 1843), the Stern Conservatorium in Berlin (1850) and the Hochschule für Musik in Berlin (1869). ${ }^{1}$

See H. van der Mescht, South African students at the Conservatory of Music in Leipzig, 1893-1914, South African Journal of Cultural History 8(2), 1994, pp. 79-88; Some South African Connections among Students at the Hochschule für Musik in Berlin, 1914-1933, South African Journal of Musicology 23, 2003, pp. 55-70; Students with South African connections at the Conservatorium of Music in Leipzig, 1843-1943, South African Journal of Cultural History 18(2), 2004, pp. 31-55; Some South African connections among students at the Hochschule für Musik in Berlin, 1869-1914, South African Journal of Cultural History 19(1), 2005, pp. 98-118; South African students at the Stern'sches Conservatorium der Musik in Berlin, 1850-1914, South African Journal of Cultural History 22(1), 2008, pp. 136-162. 
Another famous music city is Weimar, which for many years has been one of the foremost cultural cities in Germany.

Johann Sebastian Bach (1685-1750) worked in Weimar in 1703 and between 1708 and 1717, and four of his children were born there, amongst them the composers Wilhelm Friedemann (1710-1784) and Carl Philipp Emanuel (1714-1788). Johann Wolfgang Goethe (1749-1832) came to Weimar for the first time on 7 November 1775 and the city became his dwelling place. ${ }^{2}$ Here he died on 22 March 1832. Friedrich Schiller (1759-1805) lived in Weimar between 21 July 1787 and 11 May 1789 and again from 3 December 1799 until his death on 9 May 1805. ${ }^{3}$ Other famous authors were Johann Gottfried Herder (1744- Weimar 1803) and Wieland (1733- Weimar 1813). Much of what is regarded as classical ideals was founded under the Grand Duchess Anna Amalia (1739-1807). ${ }^{4}$ The versatile musician Johann Nepomuk Hummel (1778-1837) came to Weimar in 1819 as Hofkapellmeister. Like his teacher Mozart, he was a child prodigy who composed, taught and conducted. ${ }^{5}$ The celebrated pianist and composer Franz Liszt (1811-1886) performed for the first time in Weimar on 26 November 1841. On 2 November 1842 he was appointed "Kapellmeister im außerordentlichen Dienst". From 1848 he lived in Weimar on a more permanent basis until 1861, and between 1869 until his death in 1886 he divided his life between Weimar, Budapest and Rome. ${ }^{6}$ Liszt was tremendously popular as a teacher, with pupils coming from all over the world to study with him in Weimar. One of these was Hans von Bülow (1830-1894) who studied with Liszt in Weimar between October 1851 and February 1853. In 1857, Bülow married Liszt's daughter Cosima who later left Bülow and lived with Wagner from 1869. ${ }^{7}$ The author and philosopher Friedrich Nietzsche (born 1844) spent the last three years of his life in Weimar where he died on 27 August 1900 in the house which is today the Nietzsche-Archiv.

One can imagine that students studying music in Weimar would have been constantly reminded of these great minds. Places to be visited were Goethe's garden house, Goethe's house in town, Schiller's house, Hummel's grave, and the church where W.F. Bach and C.P.E. Bach were baptised.

Over the years the Music School changed its name regularly. It was created in 1872 as the Großherzogliche Orchesterschule (Grand Ducal Orchestral School) and

2 G. Günther, W. Huschke \& W. Steiner (Herausgeber), Weimar: Lexicon zur Stadtgeschichte (Weimar, 1993), p. 158.

G. Günther et al., Weimar: Lexicon (1993), p. 380.

4 Ereignis Weimar: Anna Amalia, Carl August und das Entstehen der Klassik 1757-1807: Katalog zur Ausstellung im Schlossmuseum Weimar (Leipzig, 2007).

G. Günther et al., Weimar: Lexicon (1993), p. 219.

G. Günther et al., Weimar: Lexicon (1993), p. 280.

G. Günther et al., Weimar: Lexicon (1993), p. 67. 
gradually attracted more students so that in the summer semester of 1882 (which lasted from Easter to September 1882) there were 154 students: 97 male and 47 female. There were also eight who were not doing the full course. ${ }^{8}$ The number of students with parents living abroad was standing at about five, with the parents' cities given as Christiania (Oslo), Geneva, Neufchatel, Monaco and Moscow. ${ }^{9}$

Some questions arise: Were there any students from Southern Africa who embarked on the long journey to further their music studies in the famous town of Weimar? What were the circumstances under which they studied? Who were their teachers? The aim of this exploratory article is therefore to provide particulars about students from Southern Africa who studied at the Music School. With this information further research on the later whereabouts of the students can be undertaken. This article will therefore not endeavour to explore the ensuing lives of the students. ${ }^{10}$

\section{Available sources}

Fortunately there is a good number of sources on musical life in Weimar. In a publication by Huschke (2002) the development of orchestral playing in Weimar is discussed. It starts with references to music in Weimar in $1491 .{ }^{11}$ Another publication by Huschke (1982) offers views on music in Weimar between 1756 and 1861. ${ }^{12}$

More specifically, the history of the Großherzogliche Orchester- und Musikschule and its development into the Hochschule für Musik Franz Liszt (1956-) was presented excellently in 2006 in a publication consisting of nearly 600 pages by one of the former principals, Prof. Wolfram Huschke. ${ }^{13}$

Nearly all the original student documents of the institution were destroyed in the bombings of 1945, and it is only by chance that some of the documents are still intact. Only a few of the reports of the progress of some students are available. These reports were written by hand onto printed forms.

\footnotetext{
Zweiter Bericht der Grossherzoglichen Orchester- und Musik-Schule in Weimar über die Schuljahre 1877-1882 (Weimar, 1882), p. 46.

9 Zweiter Bericht 1882, pp. 39-43.

10 The author would like to thank the National Research Foundation of South Africa for financial assistance to travel to Germany. This article is therefore based upon work supported by the National Research Foundation. Any opinions, findings and conclusions or recommendations expressed in this article are those of the author and therefore the NRF does not accept any liability in regard to these matters. Dr. Irina Lucke-Kaminiarz (Head of the Archive of the Hochschule für Musik Franz Liszt Weimar) and Mr. Thomas Wiegner of the same institution need to be thanked for their invaluable assistance. In addition, the South African Ms. Charla Schutte, previously of the Archive.

11 W. Huschke, ...von jener Glut beseelt: Geschichte der Staatskapelle Weimar (s.1., 2002), p. 9.

12 W. Huschke, Musik im klassischen und nachklassischen Weimar: 1756-1861 (Weimar, 1982).

13 W. Huschke, Zukunft Musik: Eine Geschichte der Hochschule für Musik Franz Liszt Weimar (Köln, 2006).
} 
The printed reports of the institution (at first every five years, later over smaller time periods, and then every year from 1891/1892) provide detailed accounts of the activities at the Music School. The first report's introduction ("Einleitung") does not disclose the name of the author, but one can assume that it was the founder and first director, Prof. Müller-Hartung. ${ }^{14}$ Thereafter he was responsible for the introduction (called "Schulbericht", School report) in the rest of the Berichte until 1902 when he retired after nearly 30 years. From the report of 1891 his name is spelt Müllerhartung. ${ }^{15}$ These reports are similar to the annual reports of the Conservatoriums in Amsterdam, Leipzig and Vienna, the Royal College of Music in London, and the Stern Conservatorium and the Hochschule für Musik in Berlin.

The reports have to be read with care as the names of foreign places and students are sometimes spelt incorrectly. So, for example the "Heimat" (home town) of May and Maud Henderson is given as "Creydon Surra". This would most probably by Croydon, Surrey, in England. ${ }^{16}$ The name of a student from Glasgow is given as Tolmie Sheila, which should most probably be Sheila Tolmie. ${ }^{17}$ The personal records of students were mostly lost, and of the six students discussed in this article it is only of Anna Maria Bach that we have some material.

\section{The genesis of the music school in Weimar}

The first report on the initial five years of the music school was published in Weimar in July 1877. This Erster Bericht der Grossherzoglichen Orchester- und Musik-Schule starts on p. 1 with the following declaration in the Introduction ("Einleitung"):

Under the protection of His Royal Highness the Grand Duke, an Orchestral School was opened by the management of the Court Theatre and the Court Orchestra in the middle of September 1872 according to the proposal and under the Direction of the Capellmeister Professor Müller-Hartung, who set the aim of producing thoroughly trained orchestral members, who, apart from proficiency on their instruments, also had to possess the general music training required for every achievement in art. ${ }^{18}$

14 Erster Bericht der Grossherzoglichen Orchester- und Musik-Schule (Weimar, 1877), pp. 1-2.

15 Bericht der Grossherzoglichen Musikschule in Weimar über die Schuljahre 1889 bis Ostern 1891 (Weimar, 1891), p. 5.

16 Bericht der Grossherzoglichen Musik- und Theaterschule in Weimar über das Schuljahr von Ostern 1901 bis Ostern 1902 (Weimar, 1902) p. 10.

17 Bericht der Großherzoglichen Musikschule in Weimar über die Zeit vom Mai 1902 bis Juli 1903 (Weimar, 1903), p. 16.

18 Unter der Protection S. K. H. des Grossherzogs eröffnete die Generalintendanz des Hofheaters und der Hofcapelle Mitte September des Jahres 1872 nach der Vorlage und unter der Direction des Capellmeisters Professor Müller-Hartung eine Orchesterschule, die sich als Aufgabe stellte, tüchtige 


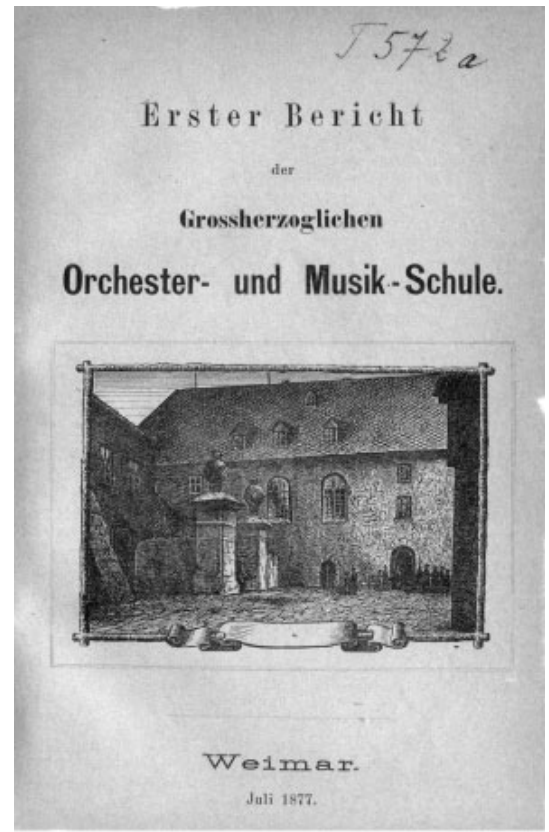

Figure 1: Cover page of the first report of the Music School in Weimar (1877)

(From: Erster Bericht der Grossherzoglichen Orchester- und Musik-Schule

(Weimar, 1877))

The School started with only 12 students. After two years the number had increased to 30. In February 1876 another section was added for lady students to learn piano playing and solo singing, as well as harmony and choral singing. In addition, a preparatory school for boys and girls of 10 years and older was created where they could study the piano and all orchestral instruments. ${ }^{19}$ The first report contains in its overview, amongst other things, lists of all the musicians who had taught at the institution, of all the students (men and women separately) of the first five years, of instruments with the names of the students taking them, of the programmes of the concerts performed, and of the students and the works each played at the student concerts (divided per instrument).

Orchestermitglieder zu erziehen, welche ausser der Fertigkeit auf ihren Instrumenten auch die zu jeder künstlerischen Leistung nothwendige allgemeine musikalische Bildung besässen. (Translations from the German are by the author of this article.)

19 Erster Bericht der Grossherzoglichen Orchester- und Musik-Schule (Weimar, 1877), p. 1. 
During its illustrious course the Music School had, according to Huschke, ${ }^{20}$ three main dates: its founding as Großherzogliche Orchesterschule in 1872, its elevation to Staatliche Hochschule für Musik in 1930 and its renaming as Hochschule für Musik Franz Liszt Weimar on 22 October 1956 on Liszt's 145th birthday.

\section{Maria Adamson}

Whereas there was a considerable number of music students with a Southern African background in Amsterdam, Berlin, Leipzig and London, the small number in Weimar, famous for its musical life and the presence of the spectres of the great Goethe, Schiller, Liszt, etc, etc, is surprising. The number of students had increased tremendously to 154 in the summer semester ("Sommerkursus") of 1882 which lasted from Easter to September 1882. There were 97 male students, 47 female students and eight who did not do the full course. ${ }^{21}$ The number of foreign students was also increasing.

In the Dritter Bericht der Großherzoglichen Orchester- und Musik-Schule in Weimar über die Schuljahre 1882-1885 one finds on p. 25 the first mention of a South African:

["Name":] Maria Adamson - ["Heimat der Eltern", home of parents:] Kapstadt [“Aufnahme”, enrolment:] Sept. 1884 - [“Fächer”, subjects:] Piano, Violine

In this semester there were 174 students in total. ${ }^{22}$ Miss Adamson had, apart from the German students, also fellow musicians whose parents were living in Athens, Bergen, Bern, Bordentown (USA; Bordertown?), Edinburgh, Geneva, Granson (?), India, Java, La Crosse (USA), Liverpool, Newbury, Philadelphia and Washington. ${ }^{23}$

It is notable that Miss Adamson's name is not found in any other place in the report. She is strangely enough not included in the lists of piano and violin students. ${ }^{24}$ And also not in the list of students who stopped studying and the list of students who left the music school. ${ }^{25}$ It might be that the publication had already been printed when Miss Adamson decided to terminate her studies. Her name is not to be found in the list of concerts given at the music school during her term of study. ${ }^{26}$

\footnotetext{
W. Huschke, Zukunft Musik (2006), p. 10.

Zweiter Bericht 1882, p. 46.

Dritter Bericht der Grossherzoglichen Orchester- und Musik-Schule in Weimar über die Schuljahre 1882-1885 (Weimar, 1885), p. 25.

Dritter Bericht 1885, pp. 21-25.

Dritter Bericht 1885, pp. 26-27.

Dritter Bericht 1885, p. 26.

Dritter Bericht 1885, pp. 36-39.
} 
Maria Adamson is not included in the list of female students given in the next report of 1886 which was the first to discuss one year only, $1885-1886 .{ }^{27}$ She would therefore have studied for at most one year.

The rules of the Music School were published in the reports, starting with the very first report in which a long list of do's and don'ts were included. ${ }^{28}$ One of these rules was the following:

Smoking on the way to the school or in the presence of a teacher without his permission, taking part in parties, dance parties and dancing events, and also in student meetings without previously obtained permission of the Director is prohibited. ${ }^{29}$

This notice was exactly repeated in the report of 1886 , nine years later, but contained more modern spelling ("Erlaubnis", "Teilnahme", "Direktors"). ${ }^{30}$

Maria Adamson makes a last appearance in the complete list of students of the first 25 years: "Adamson Maria, Capstadt (Afrika). Piano, Viol. 84-85." 11

It was a full 20 years before the next person from Southern Africa would study at the Music School.

\section{Myrtha and Ursula Noyce}

With the advent of the new director, Prof. E.W. Degner, the format of the list of students changed. Under Müllerhartung, the list gave the surname and first name ("Name"), home town ("Heimat"), enrolment date ("Aufnahme") and practical subjects ("Fächer"). ${ }^{32}$

The new format gave more information: it added the student number for the year arranged alphabetically; whether the person was a student ("S." = Schüler), preparatory student ("Vs." = Vorschüler) or only attending some subjects ("H." = Hospitant); the place of birth ("Geburtsort"); year of study ("Jahrgang"); the main instrument plus the teacher for it ("Hauptfach, Lehrer"); and additional subjects ("Nebenfächer"). ${ }^{33}$

27 Bericht der Grossherzoglichen Orchester-, Musik- und Opernschule in Weimar über das Schuljahr 1885-1886 (Weimar, 1886), p. 18.

28 Erster Bericht 1877 , p. 9.

29 Das Rauchen auf dem Schulwege oder in Gegenwart eines Lehrers ohne dessen Erlaubniss, die Theilnahme an Gesellschaften, Bällen und Tanzstunden, sowie an Schülerversammlungen ohne vorher nachgesuchte Genehmigung des Directors ist verboten.

30 Bericht 1886, p. 13.

31 Complete list of students of the first 25 years of the Grossherzogliche Orchester- und Musik-Schule (Title page lost, ca 1897), p. 48.

32 See for example Bericht 1902, p. 6.

33 Bericht 1903, p. 11. 
An amusingly transparent topic is a complete list of the hours that every teacher was teaching during the year. So, for example, the director had the following hours apart from his directorial duties: 5 hours per week of Theory classes for 22 students, 3 hours per week of Choir classes for 91 students, 4 hours of Orchestral Playing for 58 students, and 2 hours per week of Chamber Music playing for 13 students. ${ }^{34}$ To complete the reports of these students he had to mention the grand total of 184 marks.

Oschmann, the piano teacher of the two Noyce sisters/cousins, had 16 hours per week. This is less than a South African university piano professor has to teach nowadays.

At the end of the academic year 1904/1905, in which Myrtha Noyce enrolled, there were 122 students in total. ${ }^{35} 40$ came from Weimar and 31 from the rest of the Grand Duchy (Großherzogtum) of Saxony. Then there were students from other Thuringian states (5), the kingdom of Saxony (8), the kingdom of Prussia (32), the Grandduchy of Hessen (1), the Grandduchy of Mecklenburg-Schwerin (4), the Duchy (Herzogtum) of Anhalt (3), the principality (Fürstentum) of Piermont (1), England (5), America (5), India (4), Finland (1), Austria-Hungary (2), Hanover (3), Lübeck (1), Hamburg (2), Bremen (2), Alsace (1) and South Africa (1). ${ }^{36}$ Miss Noyce's line in the list of students reads: ${ }^{37}$

Noyce, Myrtha - H - Heidelberg, Süd-Afrika - 1. Jahrgang - Klav. (Oschmann).

It is most likely that Myrtha Noyce is the same person as Vivienne Frances Myrtle Noyce from Richmond in England who was born in Heidelberg, Transvaal on 18 December $1881 .{ }^{38}$ She studied at the Conservatorium in Leipzig for nearly two years, receiving her report on 3 January 1903. Before that she had studied in Gotha. If this is the same person, it means that Miss Noyce was 22 years of age when she enrolled at the Music School in Weimar, after leaving Leipzig.

Although H (= Hospitant) would imply that Miss Noyce was only attending inactively, the inclusion of a teacher's name makes one come to the conclusion that she was in fact concentrating on the piano exclusively. In Leipzig she had reached about

\footnotetext{
34 Bericht 1903, p. 9.

35 Bericht der Großherzoglichen Musikschule in Weimar über die Zeit vom Juli 1904 bis Juli 1905 (Weimar, 1905), p. 15.

36 Bericht 1905, p. 20.

37 Bericht 1905, p. 19.

38 H. van der Mescht, South African students at the Conservatory of Music in Leipzig, 1893-1914, South African Journal of Cultural History 8(2), 1994, p. 83.
} 
the present Grade 8 level of difficulty. She did not do any other subjects in Weimar. The Bericht provides a complete list of the works prescribed by poor Mr. Oschmann who had to teach the less advanced students. ${ }^{39}$ His colleagues each had his complete list printed in the Bericht. Oschmann's students had to prepare technical studies (e.g. by Pischna and Czerny) and scales; études (e.g. by Heller, Cramer-Bülow and Jensen); and easy pieces (e.g. by Bach, Mozart, Hummel, Beethoven, Schubert, Heller, Gade, Grieg and Raff). Miss Noyce was much more advanced.

During the academic year 1904/1905 there were eight public concerts given by students. These were important occasions for inexperienced students to hear more advanced colleagues performing. For example, on Monday 8 November 1904 the programme included Beethoven's Symphony No. 4, a Suite in E minor by Raff, and the Faust Overture by Wagner. The programme also included songs with piano accompaniment: Verborgenheit and Verschwiegene Liebe by Wolf (who had died the previous year) and Traum durch die Dämmerung and Heimliche Aufforderung by Richard Strauss (who had worked in Weimar between 1889 and 1894, and was still alive) ${ }^{40}$ This programme is typical of the times: famous composers are heard together with the not so famous. Moreover, works by composers with specific connections to the locus are performed.

The concert of Monday 16 January 1905 was devoted more to chamber music. ${ }^{41}$ Here, again, advanced songs by Wolf, who died in 1903, were included. Choral works with orchestra were the focus of the concert of Friday 3 February $1905 .{ }^{42}$ On Saturday 1 April 1905 the concert was devoted to works by Mozart, including the Violin Concerto in A major (with cadenzas by Joseph Joachim, born in 1831, who had played in the orchestra in Weimar under Liszt and who was in 1905 still living in Berlin). ${ }^{43}$ This is another example of a typical concert in which one famous composer is celebrated, a procedure often adopted by the Music School. The concert of Friday 14 April 1905 was given in the Stadtkirche in honour of the music-loving Grand Duchess Caroline who was born on 13 July 1884 and died on 17 January 1905 at the age of a mere 20. She was the (first) wife of the last Weimar Großherzog and a promoter of the Music School. ${ }^{44}$ The concert consisted of a performance of Brahms's Deutsches Requiem in which 225 people took part. ${ }^{45}$ In this instance, the programme can be regarded as

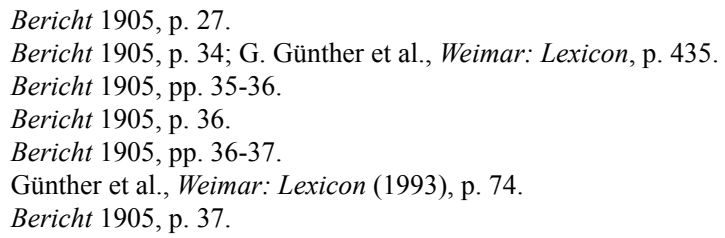


characteristic of the times. The passing away of a member of the aristocracy, who often contributed decisively to the survival of music institutions, was honoured.

The Director, Prof. Degner, set the example by presenting an organ recital on Friday 2 June 1905. His own work was the Variations for Violin and Organ on the Chorale "Aus tiefer Not schrei' ich zu dir" ${ }^{46}$ This programme is once more typical of the era when teachers played in public, including their own compositions in the programmes. A student of Degner's, Oskar Müller, was the soloist on Monday 5 June 1905 in a rendering of Rheinberger's Organ Concerto in F major. ${ }^{47}$ It is obvious that only the best students would have been "awarded" a place on the programmes of these concerts.

The year's concerts were concluded with chamber music. Oskar Müller played an Organ Prelude in E flat major by Bach. Then a performance was heard of Brahms's Sonata for Piano and Violin Op. 78, followed by three songs by Schubert: Die junge Nonne, Der Wegweiser and Die Stadt. The concert concluded with Beethoven's Piano Trio Op. 70 No. $1 .^{48}$

If Miss Noyce had attended some of these concerts she would certainly have been very impressed with the standard of difficulty of the pieces performed, as opposed to the standard of her own pieces. Her personal situation would have improved greatly in the next academic year (1905/1906) with the arrival of Ursula Noyce, probably her sister. ${ }^{49}$

According to the columns in the Bericht of 1906, Myrtha now took Choral Singing, Theory and Music History as additional subjects..$^{50}$ But it might be, though, that the printing of the page ascribed this to her while it should have been printed opposite the name of the next student's entry. Students with an H (= Hospitant) next to their names (like the two Noyce ladies) hardly ever had "other subjects" apart from their main subject. Miss Ursula had the same piano teacher, Oschmann, as Miss Myrtha and did not take other subjects. Their names are not included in the performers of the year's seven public concerts, nor did they play at the five private concerts ("Interne Schülerabende"). ${ }^{51}$

The Noyces were both born in "Heidelberg", but one is not sure whether this would be the one in the present Western Cape or in the present Mpumalanga province.

\footnotetext{
Bericht 1905, pp. 37-38.

Bericht 1905, p. 38.

Bericht 1905, pp. 38-39.

4 Bericht der Großherzoglichen Musikschule in Weimar über die Zeit vom Juli 1905 bis Juli 1906 (Weimar, 1906), p. 19.

50 Bericht 1906, p. 19.

$51 \quad$ Bericht 1906, pp. 36-40, 42-44.
} 
It is most probable that Myrtha = Myrtle, and that the Noyces were therefore born in Heidelberg, Transvaal (now in the Gauteng province). Moreover, one cannot be sure that they grew up there or that their parents were still living there (as the lists of up to 1902 seem to indicate by using the term "Heimat der Eltern"). Unfortunately, there are no written documents about the two Misses Noyce. They are not included in the list of students of the next academic year..$^{52}$

\section{Johanna (Joan) van Niekerk}

Johanna van Niekerk (later known as "Miss Joan") had enrolled for piano with August Spanuth at the Stern Conservatorium in Berlin for the academic year 1909/1910.53 As she does not appear in the Stern Conservatorium list of 1910/1911, one has to conclude that she studied there for one year only. The archival material about the Stern Conservatorium was lost, and there is therefore no further archival information about Joan van Niekerk's studies in Berlin.

The annual report of the Music School in Weimar was printed every year, but the one of 1910/1911 has unfortunately been lost and is not in the archive of the Hochschule für Musik Franz Liszt Weimar. It could be that the name of Joan van Niekerk would have been found in this lost copy. She could have come directly from Berlin to Weimar for the next year of her training. She is indicated as a second year student in the Weimar report of $1912 .{ }^{54}$ (Figure 2.)

\footnotetext{
Bericht 1907, pp. 13-17.

53 Bericht des Stern'schen Konservatoriums der Musik: 60. Schuljahr 1909/1910 (Berlin, 1910), p. 24.

54 Bericht der Großherzogl. Musikschule in Weimar Juli 1911 bis Juli 1912 (Weimar, 1912), p. 12.
} 


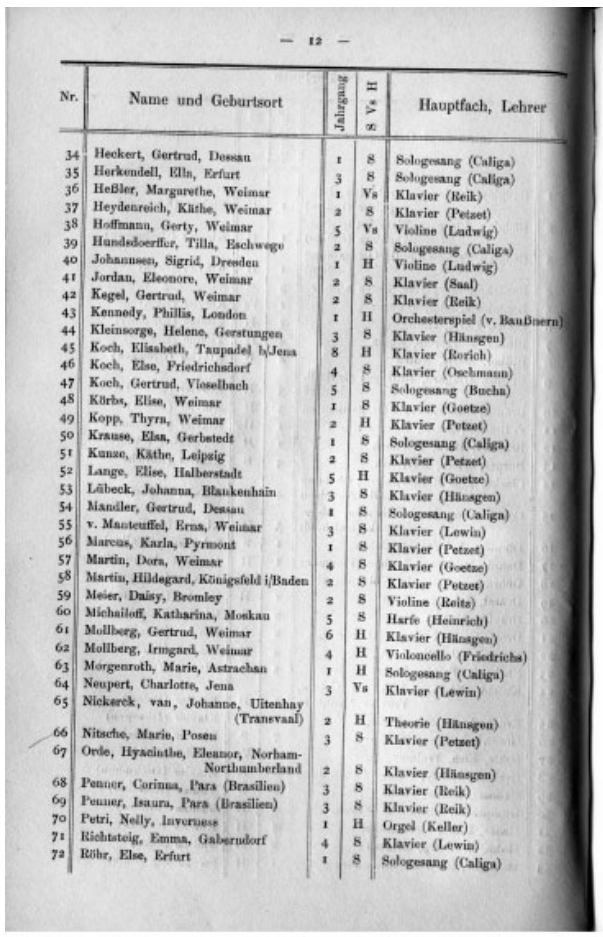

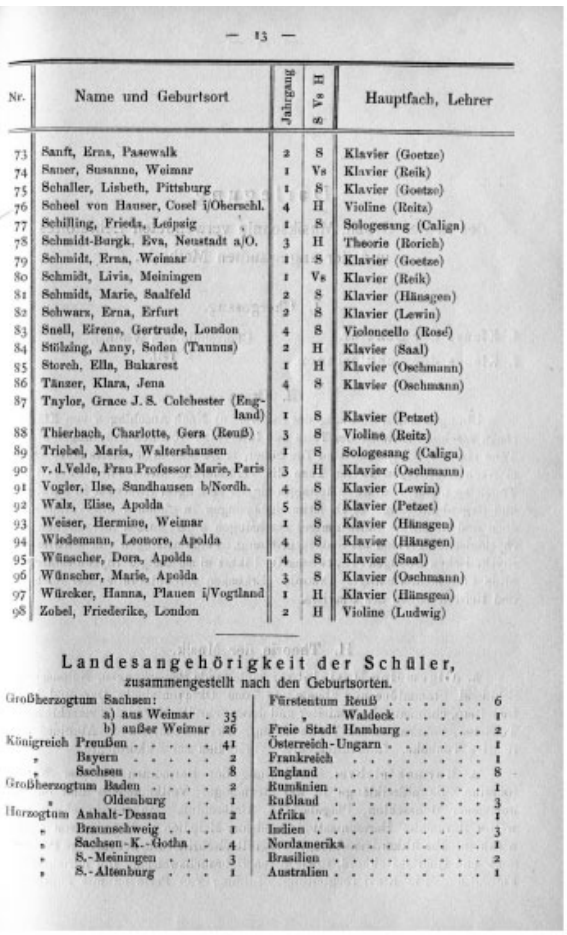

Figure 2: The list of students for the year 1911/1912 with the name of Johanna (Joan) van Niekerk (From: Bericht der Großherzogl. Musikschule in Weimar Juli 1911 bis Juli 1912, p. 12)

[Name und Geburtsort:] Nickerck, van, Johanne, Uitenhay (Transvaal) [Jahrgang:] 2. - H - [Hauptfach, Lehrer:] Theorie (Hänsgen)

The unreliability of the entries of foreign students can here be observed once more. Both Johanna van Niekerk's first name and surname are spelt incorrectly, as is the place where she was born (Uitenhage), which was not in the Transvaal but in the Cape. One can deduce that she was in her second year. (But there exists the possibility that she was placed in the second year group because of her standard, and that she was therefore actually in her first year of studying in Weimar. The Bericht containing this information has been lost.) The list of 1912 does not include the additional subjects taken as is the case in the entries of the Misses Noyce; therefore one does not know 
whether Joan van Niekerk took any other subjects. According to the list, Joan van Niekerk was the only one of the 157 students (59 male, 98 female) who took Music Theory as the main direction. ${ }^{55}$

In the list of nationalities compiled according to place of birth ("Landesangehörigkeit der Schüler, zusammengestellt nach den Geburtsorten") it is indicated that there was only one student from "Afrika". This would have been Johanna van Niekerk.

During Van Niekerk's study period at the Music School in Weimar, there were five public performances ("Öffentliche Aufführungen"), twelve public historical piano evenings ("Historische Klavierabende") and ten student concerts ("Schülerabende") presented by the Music School. ${ }^{56}$

Of the public concerts, two were devoted to Liszt whose 100th anniversary was celebrated. At the first, on Liszt's birthday on Sunday 22 Oktober 1911, his Sonata in B minor and six other pieces were performed. ${ }^{57}$ It was followed on 24 October by a performance of Liszt's Ungarische Kronungsmesse (Hungarian Coronation Mass). ${ }^{58}$

The so-called "Historische Klavierabende" (historical piano [sic] evenings), starting at 18:00, consisted, for example, on Monday 30 October 1912 of a Rondo by Couperin, three pieces by Rameau, three pieces by Domenico Scarlatti, The harmonious blacksmith by Handel and the Chromatic Fantasy and Fugue by Bach. ${ }^{59}$ The next concert, on Tuesday 21 November 1912, offered compositions by Paradis, Wilhelm Friedemann and Carl Philip Emanuel Bach (both born in Weimar), Johann Christoph Bach, Haydn and Mozart. ${ }^{60}$ The idea of presenting a concert containing a central theme is illustrated again in the next concert of Tuesday 5 December 1911, which was exactly 120 years after Mozart's death. ${ }^{61}$ Three days after Beethoven's birthday, on Tuesday 19 December 1911, a programme of his piano works was presented. ${ }^{62}$ The programme of Tuesday 30 January 1912 included the Sonata in E flat major by Hummel who worked in Weimar and died there on 17 October $1837 . .^{63}$ Another programme was devoted exclusively to Chopin on Saturday 2 March

\footnotetext{
Bericht 1912, p. 13.

Bericht 1912, pp. 24-42.

Bericht 1912, p. 24.

Bericht 1912, p. 24.

Bericht 1912, p. 28.

Bericht 1912, p. 28.

Bericht 1912, p. 29.

Bericht 1912, p. 29.

Bericht 1912, p. 30.
} 
$1912 .{ }^{64}$ Schumann's piano works were celebrated on Thursday 28 March $1912^{65}$ and works by "minor" composers were on the programme of Saturday 27 April: Jensen, Kirchner, Bargiel, Reinecke, Raff and Rheinberger. ${ }^{66}$ On Thursday 6 June 1912 the programme consisted of works by Brahms ${ }^{67}$ The last piano evening presented works by contemporary composers: Draeseke, Nicodé, Philip Scharwenka, Moszkowski, Richard Strauss and Max Reger. ${ }^{68}$

Joan van Niekerk would most probably have attended this amazing concert series which presented an overview of keyboard compositions from Couperin to contemporary composers.

In town she could have heard many other performances, for example the centenary celebrations of Liszt's birth. On 20 October 1911 the programme in the Großsherzogliches Hoftheater consisted of the symphonic poem Hungaria, the work for piano and orchestra Totentanz, and the "Faust" Symphony. ${ }^{69}$ And on Liszt's exact birthday, 22 October, his oratorio Legende von der heiligen Elisabeth was performed. Joan van Niekerk is not included as a performer in the ten student concerts. ${ }^{70}$

The South African Music Encyclopedia states that Van Niekerk was born about $1900 .{ }^{71}$ She would therefore have been about eleven years old when she started studying at the Music School in Weimar. This is highly unlikely. Her birth date could more possibly be guessed as about 1890. Stegmann does not mention her studies in Weimar. After her European sojourn she taught in Germiston and settled in Stellenbosch in 1924. She became well-known as an accompanist to the soprano Gladys Hugo and others. Her main contribution is her very important volume Die Groot AfrikaanseHollandse Liederbundel (The big Afrikaans-Dutch Volume of Songs) published in 1927. She taught singing at the Conservatorium of the University of Stellenbosch. ${ }^{72}$ Grové mentions “c. 1900" as her date of birth, as well as studies in Vienna. Nothing is mentioned about her studies in Berlin and Weimar. ${ }^{73}$

\footnotetext{
64 Bericht 1912, p. 31.

65 Bericht 1912, pp. 31-32.

66 Bericht 1912, p. 32.

67 Bericht 1912, p. 33.

68 Bericht 1912, p. 34.

69 W. Huschke, ...von jener Glut beseelt (2002), p. 172.

70 Bericht 1912, pp. 35-42.

71 F. Stegmann, Van Niekerk, Johanna (Joan), in J.P. Malan (ed), South African Music Encyclopedia IV (Cape Town, 1986), p. 421.

72 I.J. Grové (red.), Konservatorium 1905-2005: Die Departement Musiek en die Konservatorium van die Universiteit Stellenbosch by geleentheid van die Eeufees 1905-2005 (Stellenbosch, 2005), p. 145 .

73 I.J. Grové (red.), Konservatorium 1905-2005 (2005), p. 132.
} 
The zoologist and author C.G.S. (Dr. Con) de Villiers included a humorous sketch called "Gladys en Joan en ek" (Gladys and Joan and I) in his publication Musici en mense (Music and people). He paints the concerts given by the soprano Gladys Hugo with Joan van Niekerk at the piano, writing that "Miss Joan" was without any doubt the best accompanist South African had produced. ${ }^{74}$ The author of this article remembers Joan van Niekerk sitting at the piano accompanying a singer at an eisteddfod in Stellenbosch in the late 1960s. According to the findings of this research, she must have been in her late seventies. She died on 5 September 1972 in Somerset West. ${ }^{75}$

It is clear that research on Joan van Niekerk's life and contributions is long overdue.

\section{Thyra Nissen-Lass}

It is evident from the student names in the annual report during the war years from 1914 to 1918 that there were still many foreign student studying music in Weimar. The introduction to the report of 1915 (that is after World War I had started) commences with the following words: ${ }^{76}$

The outbreak of the war with its consequences united all music training institutions to some degree in sympathy. Everywhere a certain decline in the student numbers was noticed which was shown in the first place among male students of conscription age. Student attendance at the Music School suffered comparatively little, as the student numbers reached two thirds of the normal number during the war year. ${ }^{77}$

The Großherzogliche Musikschule was surviving in spite of difficult circumstances. In the report of 1917 the following is explained about the Music School's position after two years of war: ${ }^{78}$

74 C.G.S. de Villiers, Gladys en Joan en ek, in C.G.S. de Villiers, Musici en mense (Kaapstad, 1958), p. 56 .

75 F. Stegmann, Van Niekerk, Johanna (Joan), in J.P. Malan (ed), South African Music Encyclopedia IV (1986), p. 421.

76 Bericht der Großherzoglichen Musikschule in Weimar Juli 1914 bis Juli 1915 (Weimar, 1915), p. 3.

77 Der Ausbruch des Krieges mit seinen Folgen hat alle musikalischen Bildunganstalten mehr oder weniger in Mitleidenschaft gezogen. Überall zeigte sich ein gewisser Rückgang der Schülerzahl, der sich in erster Linie auf die Schüler in militärpflichtigem Alter erstreckte. Der Schülerbesuch der Großherzoglichen Musikschule hat verhältnismäßig wenig gelitten, denn die Schülerzahl erreichte im Kriegs-Schuljahr zwei Drittel der normalen Höhe.

78 Jahresbericht der Großherzoglichen Musikschule zu Weimar: Schuljahr 1916/17 (Weimar, 1917), p. 6. 
In spite of the burdensome influences of the war, which caused, with its constantly expanding conscription, a very small remaining number of male students and obviously excluded foreign students almost completely, the school was happy about the considerable rise in attendance. ${ }^{79}$

The report also mentions the fact that there was a lack of heating material ("Heizmaterial") so that the Music School had to confine itself to only some of its rooms, and some teachers taught at home. ${ }^{80}$

Among all the male students there was only one from outside the Germanspeaking countries: Hans Lapidoth, a Dutch citizen born in Paris. ${ }^{81}$ And among the female students there were, apart from students from all over the German Reich and Austria, only one foreigner. In the Jahresbericht der Großherzoglichen Musikschule zu Weimar: Schuljahr 1916/1 $7^{82}$ the name can be found of

["Name und Geburtsort", name and place of birth:] Nissen-Laß, Thyra, Windhoek, Dtsch.-Südw.-Afrika - [“Jahrgang", year:] 1 - V ["Vollschüler", full student:] - [“Hauptfach, Lehrer”, main subject, teacher:] Klavier (Hänsgen).

Miss Nissen-Lass was therefore born in Windhoek in the present Namibia and studying the piano with the same teacher with whom Joan van Niekerk had studied Music Theory. One cannot necessarily deduce that her parents were still in Windhoek. In the separate overview of the origins of students, it is indicated that Miss Nissen-Lass was from "Deutsch-Südwest-Afrika". ${ }^{83}$

She stayed at the Music School for four years, changing her teacher for the young Miss Hedwig Hinz in her third year. ${ }^{84}$ For this third year, Miss Nissen-Lass is indicated as a "Gastschüler", a guest student. ${ }^{85}$ This might be a mistake as she is again mentioned as a "Vollschüler" (full student) the next year. ${ }^{86}$ But it could also

79 Trotz aller erschwerenden Einflüsse des Krieges, der mit den immer weiter greifenden Einberufungen eine verschwindend kleine Zahl an männlichem Schülermaterial bedingt und das Ausländertum z. B. naturgemäß fast völlig ausschaltet, hat sich die Schule eines erheblich steigenden Besuches zu erfreuen.

80 Jahresbericht 1917, pp. 6-7.

81 Jahresbericht 1917, p. 10.

82 Jahresbericht 1917, p. 12.

83 Jahresbericht 1917, p. 14.

${ }^{84}$ Jahresbericht der Großherzoglichen Musikschule zu Weimar: Schuljahr 1917/18 (Weimar, 1918), p. 13; Jahresbericht der Landes-Musikschule (vormals Großherzoglichen Musikschule) zu Weimar: 47. Schuljahr 1918/19 (Weimar, 1919), p. 15; Jahresbericht der Staatlichen Musikschule zu Weimar: 48. Schuljahr 1919/1920 (Weimar, 1920), p. 12.

85 Jahresbericht 1919, p. 15.

86 Jahresbericht 1920, p. 12. 
be that she did not have enough money to do the complete course. Miss Hinz had been a foremost piano graduate who, as a student of Bruno Hinze-Reinhold, had won the Stipendium of the Bertrand Roth-Stiftung (Foundation) ${ }^{87}$ She was appointed on 1 January $1917 .{ }^{88}$

The director of the Music School was now Professor Bruno Hinze-Reinhold who taught the piano. There were 161 students at the Music School during the course of this year of whom, due to the war, only 51 were male. ${ }^{89}$

As previously, there was a number (eleven) of student concerts, another student concert in aid of the Red Cross, and one where only music by Mozart was played. In the other concerts students could, for example, hear the director, Hinze-Reinhold, playing Beethoven's complete piano trios with the violinist Robert Reitz and the cellist Eduard Rosé (see later) on the Mondays of 2, 9 and 16 October $1916 .{ }^{90}$

Miss Nissen-Lass's experience at the Music School can now be read together with that of the next student.

\section{Anna Maria Bach}

During the same year that Miss Thyra Nissen-Lass enrolled (1916), there was a first year student by the name of Anna Maria Bach. She was from Allenstein in East Prussia ${ }^{91}$ and was studying the piano with the versatile Konzertmeister Eduard Rosé who, amazingly, was both a cello and a piano teacher. ${ }^{22}$ She was therefore a typical German student coming from a German environment.

But in the Jahresbericht der Großherzoglichen Musikschule zu Weimar: Schuljahr 1917/18, which had changed the format of the list of students (moreover, for the first time, providing one list of all students, male and female), the following entry is found:

Bach, Anna Maria - [Heimat:] Windhuk, D.-S.-W.-Afrika - [Staatsangehörigkeit:] Preußen - [Jahrgang:] 2. - S [= Vollschüler, full student $]$ [Hauptfach:] Klavier - [Lehrer:] Rosé

It would seem as though the parents of Anna Maria Bach had moved to Windhoek in the German colony of Southwest Africa. ${ }^{93}$ Her "Heimat" was where her parents lived,

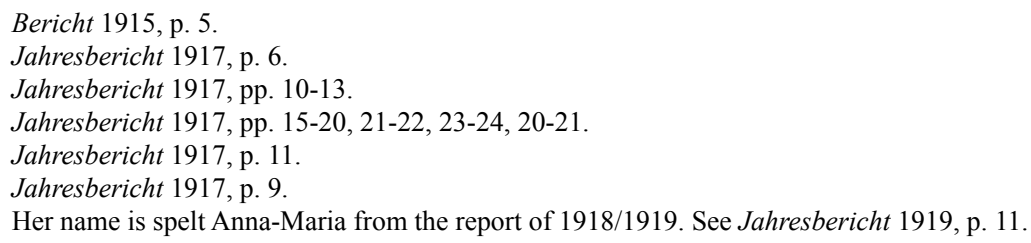


and that was Windhoek. In this way she was also connected to Myrtha Nissen-Lass who came from Windhoek. Whereas Miss Bach was a Prussian citizen, Miss NissenLass's citizenship was indicated as "Deutsche Kolonie". 94

The Music School was still suffering under the consequences of World War I, but was doing well. The positive attitude is reflected in the report that appeared in the Jahresbericht der Großherzoglichen Musikschule zu Weimar: Schuljahr 1917/18:95

The world war which is still raging does therefore not manage to paralyze interest in music, but on the contrary rather enhances it. The stronger need for serious art and musical advancement can be explained by the longing for diversion from all that is unbearable, brought on by these times. Music has the power like no other art to console us and uplift us. ${ }^{96}$

The report tells of two very talented students who had fallen in the war ${ }^{97}$ and another one who had died of his wounds. We lament the loss of these young men bitterly and will always remember them with honour! ${ }^{98}$

During the year 1917/1918, the Misses Nissen-Lass and Bach could hear twelve student concerts. ${ }^{99}$ Among the five other public concerts (in some of which students also took part) the Bach concert of Saturday 22 June 1918 was perhaps the most special. It was dedicated to the memory of Grand Duke Carl Alexander of Saxony whose 100th birthday was celebrated. ${ }^{100}$ The concert consisted of the Concerto for Two Pianos in C major, the aria "Es ist vollbracht" from the Cantata Sehet, wir gehn hinauf gen Jerusalem, the Brandenburg Concerto No. 3, the Cantata Ich will den Kreuzstab gerne tragen, and the Concerto for Three Pianos.

After the end of the war the Music School was severely affected by the revolution and the creation of the republic on 11 August 1919. The report of 1918/1919 starts in the following way: ${ }^{101}$

$94 \quad$ Jahresbericht 1919 , p. 5.

96 Der immer weiter tobende Weltkrieg vermag also das Interesse an Musik nicht zu lähmen, sondern im Gegenteil eher zu erhöhen. Das stärkere Bedürfnis nach ernster Kunst und musikalischer Förderung ist wohl zu erklären durch das Verlangen nach Ablenkung von allem Schweren, was diese Zeiten bringen. Vermag doch die Musik wie keine andere Kunst uns Trost zu bringen und uns zu erheben.

97 Verlust zweier hochbegabter und liebenswerter Schüler.

98 Wir beklagen den Verlust dieser Jünglinge auf das schmerzlicheste und werden ihr Andenken stets in Ehren halten!

99 Jahresbericht 1918, pp. 16-23.

100 Jahresbericht 1918, p. 25.

101 Jahresbericht 1919, p. 3. 
The revolution of 9 November 1918 shocked the still further expanding Großherzogliche Musikschule seriously. It lost through the abdication of His Royal Highness the Grand Duke Wilhelm Ernst its protector and patron. ${ }^{102}$

The name of the institution now had to be changed to Landes-Musikschule. But the number of students had increased dramatically with the change of sentiments after the war: There were now 297 students. ${ }^{103}$ When the Misses Nissen-Lass and Bach enrolled during the year 1916/1917 there were only 161 students in total. ${ }^{104}$ After two years with Eduard Rosé, Miss Bach changed her teacher to Hermann Oschmann who had taught the two Noyce students (see above). ${ }^{105}$

The extraordinary persons with whom the Southern Africans came into contact can be illustrated by focusing on the life of Miss Bach's teacher Eduard Rosé. By the time he started teaching her in 1917 at the age of 58, he had already experienced an astonishing music career. He was born with the last name Rosenblum in Romania on 29 March 1859. ${ }^{106}$ The family moved to Vienna where Eduard Rosenblum studied at the Conservatorium, Mahler being one of his contemporaries. On 11 July 1878 Eduard played in a performance of Mahler's Quintet for Strings and Piano for which Mahler had won a prize ("Abschlußpreis") at the Conservatorium. Eduard's brother, the violinist Arnold (1863-1946), founded a string quartet in 1882, a year in which they adopted the stage name Rosé. The Rosé Quartet gave the premières of string quartets by Brahms, Pfitzner, Schönberg and Reger. From October 1884 to September 1887 Eduard Rosé worked as first solo cellist in the Court Opera Orchestra in Budapest. After a period as freelance musician, Eduard Rosé was appointed from October 1891 to the Boston Symphony Orchestra under Artur Nikisch (1855-1922). In this year he converted to Protestantism. During a holiday in Europe, Rosé married Mahler's sister Emma on 2 June 1898 in Vienna. From September 1900 Rosé became the first cellist of the Court Orchestra in Weimar. In addition, he was appointed cello and

\footnotetext{
102 Die Revolution des 9. November 1918 erschütterte die immer weiter aufblühende Großherzogliche Musikschule aufs schwerste. Verlor sie doch durch den Thronverzicht Seiner Königlichen Hoheit des Großherzogs Wilhelm Ernst ihren bisherigen Schirmherrn und Erhalter.

103 Jahresbericht 1919, pp. 11-18.

104 Jahresbericht 1917, pp. 10-13.

105 Jahresbericht 1919, p. 11.

106 B. Post, Tod in Theresienstadt, Kulturverlust: Ausstellung im Deutschen Nationaltheater Weimar 11. Mai-7. Juli 2002 (No place, 2002), p. 51.
} 
piano teacher at the Music School. ${ }^{107}$ It is obvious that every student at the Music School could learn a great deal from his experience.

During the academic year of 1918/1919 eleven student concerts were given, in none of which the two students from Windhoek were engaged. Four of the five public concerts were also presented by students, of which one consisted of scenes from Schiller's Don Carlos performed by students from the drama class. ${ }^{108}$ In the other three concerts students appeared with the orchestra, and the fifth concert was presented by teachers. The Windhoek students are also not to be found in the report of concerts of 1919/20, the last year of Myrtha Nissen-Lass's studies.

Anna Maria Bach studied for another year, the academic year 1920/1921, and her name is once more not to be found among the names of students who participated in the student or other concerts. One has to deduce that the two ladies from Africa had not progressed far enough to appear in public.

During this time, the wide variety of compositions to be heard at the public and student concerts was again noticeable. So, for example, on Wednesday 27 October 1920 there was a special concert in honour of Liszt who had spent so much time in Weimar and had contributed much to the development of the Music School. ${ }^{109} \mathrm{~A}$ series of three concerts was given in honour of Beethoven's 150th birthday. ${ }^{110}$ Another concert was termed "Orchester-Konzert (Alte Musik)", orchestral concert (old music). It featured works by Stamitz, C.P.E. Bach and J.S. Bach. ${ }^{111}$ On Thursday 30 June 1921 there was a concert of Bach works of which the first half consisted of organ works and the second of piano works. ${ }^{12}$ Moreover, during the 22 student concerts of the year 1920/1921, Beethoven's 150th birthday was celebrated. ${ }^{113}$

107 With the deteriorating social circumstances of persons of Jewish descent, Rosé fell into difficult times after his retirement from the Music School in 1924 and the orchestra in 1926. His wife died on 8 June 1933. His two sons returned in great danger to Weimar in 1939 for his $80^{\text {th }}$ birthday. The son Ernst reached America and died in Washington D.C. in 1988. The pianist Wolfgang Rosé managed to leave Germany as late as 1941 and settled in America. During the next year he was on a nationwide tour with the Russian bass Alexander Kipnis. He died during a visit to Austria in 1977. Eduard Rosé's fate was terrible: He suffered unbearable humiliation in Weimar, was transported on 20 September 1942 (at the age of 83) to Theresienstadt (now in the Czech Republic) and died there on 24 January 1943. See B. Post, Tod in Theresienstadt (2002), pp. 51-56.

108 Jahresbericht 1919, pp. 27-20.

109 Jahresbericht der Staatlichen Musikschule zu Weimar: 49. Schuljahr 1920/21 (Weimar, 1921), p. 15.

110 Jahresbericht 1921, pp. 16-17.

111 Jahresbericht 1921, p. 19.

112 Jahresbericht 1921, p. 20.

113 Jahresbericht 1921, pp. 28-29. 
It is a great surprise to find that the Archive of the Hochschule für Musik Franz Liszt Weimar possesses five documents on Anna-Maria Bach which will (as opposed to the cases of the other five students discussed in this article) shed more light on who she was and what she achieved. ${ }^{114}$

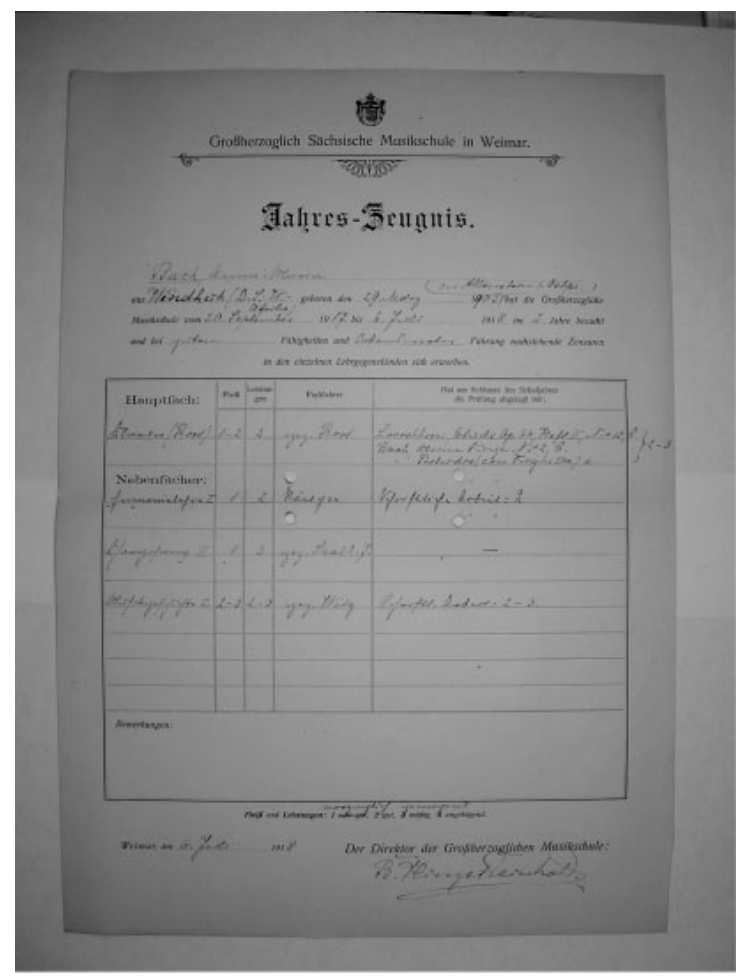

Figure 3: Jahres-Zeugnis of Anna Maria Bach, 6 July 1918 (From: Archive of the Hochschule für Musik Franz Liszt Weimar, File B29)

The first one is an annual report (Jahres-Zeugnis) for the year 1917/1918, signed by the Director, Prof. Hinze-Reinhold, on 6 July 1918. (See Figure 3.) The A3 paper carries the caption "Großherzoglich Sächsische Musikschule in Weimar". The document now discloses that Miss Bach was from "Windhoek (D.S.-W.-Afrika)" and that she was

114 Archive of the Hochschule für Musik Franz Liszt Weimar, File B29. 
born on 29 March 1903 in Allenstein in East Prussia. She was therefore only 13 years old when she enrolled for the first time in 1916. Her abilities were regarded as good and her conduct praiseworthy. At the bottom of this certificate the numbers awarded are explained as 1 = "vorzüglich" (excellent); 2 = "gut" (good); 3 = "genügend" (adequate), and 4 = "ungenügend" (inadequate). For her main subject (piano) AnnaMaria received 1-2 for "Fleiss" (diligence) and 2 for "Leistungen" (achievements) from her teacher Eduard Rosé. Her pieces were rather simple: a Loeschhorn Étude from Op. 66, Little Fuge No. 2 by Bach, and Preludio con Fughetta by Bach. For all of these she received the mark of 2-3. For the first year of Harmony she received 1 for "Fleiss" and 2 for "Leistungen" from Hänsgen, and for her written work she was awarded a 2. She attended the second year of choral singing for which she gained a 1 for "Fleiss" and a 3 for "Leistungen". The teacher was Hermann Saal Jr. In the first year of History of Music, for which her teacher was Richard Wetz, she was awarded 2-3 for "Fleiss" and 2-3 for "Leistungen". For her written work she attained 2-3.

There are also reports for 1918/1919, 1919/1920 and 1920/1921. According to the reports she was now studying the piano with Oschmann. In the first two reports Miss Bach received 2, 2-3 or 3 for the rubrics "Befähigung", "Fleiß" and "Leistungen". But, improving, in the last one she was awarded for her piano playing a 2 for "Befähigung", 1-2 for "Fleiß" and 2-3 for "Leistungen". For her History of Music she was awarded 2 for "Befähigung", 2 for "Fleiß" and 2-1 (?) for "Leistungen". In her annual report of $1918 / 1919$ it is disclosed that she does not receive the report ("Erhält kein Zeugnis, da sie in Harmonielehre zu lange fehlen mußte"), because she was apparently prevented from attending enough of the Harmony classes. The report of 1919/1920 states that she does not receive the report because she did not attend the Theory classes ("Erhält kein Zeugnis, da sie Theorie nicht besucht hat.”). The last report (1920/1921) states bluntly: "Kein Zeugnis!” (No report!). It is evident that Anna Maria Bach was not as diligent in Theory as might have been expected.

The payment document of 1920/1921 (a little smaller than A4 size), signed on 16 September 1920, shows that her father was Hugo Bach, a chief judge ("Oberrichter") in "Windhuk". Anna-Maria Bach was staying at 25 Schröterstrasse in Weimar.

One wonders whether Anna Maria Bach took the opportunity of hearing Wagner's Ring des Nibelungen in the Deutsches Nationaltheater, as it was now called. It started with Das Rheingold on Friday 3 June 1921. ${ }^{115}$

115 W. Huschke, ...von jener Glut beseelt (2002), p. 174. 


\section{Conclusions}

From its inception in 1872 until 1939 at the outbreak of World War II there were surprisingly only six students with Southern African connections studying at the Music School in the famous music city of Weimar. They were Maria Adamson (Cape Town), Myrtha and Ursula Noyce (Heidelberg, Transvaal), Johanna (Joan) van Niekerk (Uitenhage), Thyra Nissen-Lass (Windhoek) and Anna Maria Bach (Windhoek).

As these students were not mentioned in the programmes of student concerts, one has to assume that they were not of a standard to perform in public with the other students. The vibrant music life at the Music School and in the town of Weimar would have trained them in addition to the classes they received. The research has shown that there was an amazing variety of music to be heard at the Music School.

It therefore remains to be determined where these persons lived and worked after their Weimar student days. With their excellent background they would have contributed greatly to the musical life of any town or city. The ensuing musical lives of these six ladies would provide interesting material for further research. It is only of Joan van Niekerk that we have further particulars about her life, however scant. She is the only one to be included in Malan's South African Music Encyclopedia, ${ }^{116}$ but she is not mentioned in the Dictionary of South African Biography ${ }^{117}$ in spite of her seminal volume Die Groot Afrikaanse-Hollandse Liederbundel ${ }^{118}$ which was the forerunner of the Afrikaans FAK Sangbundel (the FAK song volume) ${ }^{119}$ which was used by many Afrikaners.

116 F. Stegmann, Van Niekerk, Johanna (Joan), in J.P. Malan (ed), South African Music Encyclopedia IV (1986), p. 421.

117 W.J. de Kock (ed.), Dictionary of South African Biography I (Cape Town, 1968); W.J. de Kock \& D.W. Krüger (eds.), Dictionary of South African Biography II (Cape Town, 1972); D.W. Krüger and C.J. Beyers (eds.), Dictionary of South African Biography III (Cape Town, 1977); C.J. Beyers (ed.), Dictionary of South African Biography IV (Durban, 1981); C.J. Beyers \& J.L. Basson (eds.), Dictionary of South African Biography V (Pretoria, 1987).

118 J. van Niekerk (samest.), Die Groot Afrikaanse-Hollandse Liederbundel (Kaapstad, 1927).

119 See the introduction to this volume where her name and publication are mentioned. H. Gutsche, W.J. du P. Erlank \& S.H. Eyssen, Die F.A.K.-Volksangbundel (Pretoria, 1937), p. v. 